\title{
Kuura Irni
}

\section{Queering Multispecies Bonding: Reading Donna Haraway's Dog Stories as Queer Feminism ${ }^{1}$}

Introduction. At this moment, focusing on the connections among queer, feminist, and animal studies has remained the task of a few but important inaugural articles, essays, and collections. ${ }^{2}$ Previous feminist debates regarding queer theory and nonhuman animals largely concentrated on identifying and discussing so-called "queer" or "trans" animals, or critiquing such accounts (e.g., Alaimo; Hird; Sullivan). In this paper I will instead develop a queer theoretical perspective that focuses on questioning norms, not on identities. By conducting a queer theoretical reading of Donna Haraway's work on dogs as significant others and companion species, I explore some of the ways that are or could be available for conceptualizing affection in relationships with nonhuman animals.

Haraway has been extremely critical of referring to dogs as furry "children." 3 Addressing this critique also, I explore Haraway's alternative account of her affection for the dog, Ms Cayenne Pepper, and her other stories related to dogs. I argue that reading Haraway's writing on dogs from a queer theoretical perspective and in terms of her alternative accounts of dog love demonstrates that they critique more than the problematic anthropomorphizing of nonhuman animals. I suggest that Haraway's critique, epitomized by her slogan "make kin, not babies" (Staying with the Trouble 102), relates to her call to imagine new constellations of family and kin not dependent on biological inheritance or anthropocentric understandings of significant relationships. I read in this an affinity with the queer theoretical critique of family and relationship norms. ${ }^{4}$

James Stanescu, Sanna Karhu, and Noreen Giffney are among the authors that have inspired my take on queer theory as critique of norms. While a wide variety of queer theoretical perspectives focus on temporality, activism, or place, this paper addresses rethinking normative relationship patterns. Here, queer theory does not concentrate on non-heterosexual identities or behaviors, whether human or nonhuman; rather, it focuses on, in Noreen Giffney's formulation, "norms for the way they define, solidify, and defend their shaky self-identities by excluding those (dissident others) who fail or refuse to conform" (Giffney 75). My focus is on norms related to the formation of families and relationships, and the norms concerning which relationships are 
understood as significant and valuable. In particular, I focus on alternatives to normative perceptions of relationships. ${ }^{5}$ I critically assess the assumption and ideal that intimacy, sex, and romantic love are involved in, as well as restricted to, a couple relationship between people, and the centrality of reproduction in the conceptualization of relationships in both people and nonhuman animals. Where these ideals prevail, they lead to the devaluation of a range of alternative constellations of significant relationships and "kin" among people, as, for example, communal living, chosen families, significant relationships with nonhuman animals, non-monogamous relationship patterns, asexual or aromantic relationships, and friendships. I read Donna Haraway's work on dogs as an intervention into the normative and anthropocentric, mostly so-called "Western," White ideals of kinship, and I view it as an opening up of an alternative, non-anthropocentric queer perspective. In other words, I suggest that Haraway's work can be read and developed as an intervention into thinking through multispecies kinship from a queer feminist perspective.

In building my queer theoretical approach as specifically feminist animal and multispecies studies work, I am also inspired by ecofeminisms and critical animal studies that stress the importance of the agency and subjectivity of nonhuman animals, critically addressing the killing and ill-treatment of them, and working towards more resilient relationships with them. ${ }^{6}$ Family and relationship norms are relevant for critical animal studies because they also tend to narrow the ways in which nonhuman animals can be understood and narrated as significant companions.

I share Haraway's and other feminist scholars' fascination with stories as part of doing science and feminist theory, in reflecting and building relationships with otherswhether people or nonhumans - and in trying to find "an absent, but perhaps possible, other present" (Haraway, "The Promises of Monsters" 63).7

\section{Making kin with animal companions.}

"(I)t is high time that feminists exercise leadership in imagination, theory, and action to unravel the ties of both genealogy and kin, and kin and species." (Haraway, Staying with the Trouble 102).

One value of queer theory for animal and multispecies studies lies in problematizing the heteronormative understandings of kinship and intimacy, including questioning the normativity and primacy of couple relationships, as well as reproductive futurism, where the figure of the child is central for imagining futures (Edelman). Moreover, 
Haraway's thinking has affinity with the queer theoretical concept of chosen families and the rethinking of heteronormative notions of kinship and genealogy (e.g., Butler, Undoing Gender; Weston), when she proposes that we should think of kin and kind as not necessarily tied to ancestry or genealogy (Staying with the Trouble 102-103). ${ }^{8}$ In Staying with the Trouble, Haraway's proposition includes the wish that "making kin and making kind (as category, care, relatives without ties by birth, lateral relatives, lots of other echoes) stretch the imagination and can change the story" (103).

For Haraway, in contrast with most queer scholars, making kin includes nonhumans, and it is crucial how Haraway includes them. In the context of companionship with animals, Haraway fiercely objects to familial constructions related to dogs: "contrary to lots of dangerous and unethical projection in the Western world that makes domestic canines into furry children, dogs are not about oneself" (Haraway, Companion Species 11). This relates to the critique by critical animal studies scholarship, which draws attention to the power relations, exploitation, and domination of nonhuman animals inherent in the relations between humans and other animals. ${ }^{9}$ This critique also addresses the use of so-called companion animals as mere commodities for human pleasure and amusement (Francione), and training and breeding them to demonstrate human power over them (Tuan). Furthermore, the legal classification of companion animals as possessions of their human "owners" allows them to be, for example, "euthanized at the whim of the owner" (Cudworth 150; see also Torres).

As these critical studies demonstrate, a power relation is a central condition of domestic animals' lives. However, as Erika Cudworth observes, nonhuman animals who live as part of households are not merely outlets for humans' needs to show affection, nor are they a projection of idealized relationships among humans (146). Within animal studies, a few scholars have taken a critical position that questions whether peoples' relations with their animal companions is only a matter of humans dominating other animals. Two important issues related to this need to be raised here. First, Sunaura Taylor, elaborating on what she calls the feminist disability ethic-of-care, criticizes the assumed dichotomy between independence and dependence ("Interdependent Animals" 113). In order for relationships between people and nonhuman animals to be ethical, there is not, and should not be, a requirement or assumption that all parties are independent or autonomous. Rather, a feminist animal studies perspective should be attentive to the ways in which speciesism and ableism work together "to render dependency [of both humans and other animals] an even more justifiable and righteous reason for exploitation" (117). Thus, the response to the issue of dependency should not be the fantasy of eradicating it from relations between humans and other animals, as it is not

Humanimalia: a journal of human/animal interface studies

Volume 12, Number 1 (Fall 2020) 
eradicable from relations among people. Rather, the task is to be sensitive to the agency and subjectivity of nonhuman animals while being aware of and assessing the relationship of dependency that is involved.

Second, Haraway generally operates with the notion of companion species, not companion animals, and this also concerns dogs. The distinction is important; Haraway sees the problem in conceptualizing dogs as "children" as part of a broader problem of infantilization and commodification. As she explains in When Species Meet: "'companion species' does not mean smallish animals treated like indulged children-in-fur-coats (or in fins or feathers) in late imperial societies" (165). ${ }^{10}$ The concept of companion species involves questioning human exceptionalism, focusing on ontology and relationality"(e)very species is a multispecies crowd" - and questioning categorization: "Companion species is a permanently undecidable category." Haraway writes: "Neither is the dog the same as a child nor an aged parent. .. parent-child, guardian-ward, and owner-property are all lousy terms for the sorts of multispecies relationships emerging among us.... The categories need a makeover" (51, emphasis in original).

The nonhuman animals with whom people live and who may be significant others are not companion animals whose purpose is to meet people's needs; rather, they are animal companions, with their own demands and interests in the relationship, which defy placing them into predetermined categories. Here, according to Haraway, the human partner has a care responsibility that is different from caring for a child: "If we live with our animal companions at home as adults of another species, and not as furry children or weird dispensers of 'unconditional love,' we have a chance to care more broadly" (Potts and Haraway 326). Like Erica Fudge's claim that nonhuman animals are loved not because they compensate for children or other humans but precisely because they are not humans (20; see also Cudworth 147), Haraway suggests: "Indeed, that is the beauty of dogs. They are not a projection, nor the realization of an intention, nor the telos of anything. They are dogs, i.e., a species in obligatory, constitutive, historical, protean relationship with human beings" (The Companion Species Manifesto 11-12).

Developing queer feminist animal studies with Haraway. To conceptualize love for a specific dog, Ms Cayenne Pepper, Haraway utilizes neither a conceptualization of love derived from cultural narratives of love between a mother and a child, nor of friendship (for an analysis of calling relations with dogs, friendship, see Townley). In Haraway's narrative, affection for a nonhuman companion involves physical intimacy that 
resembles a romantic relationship: kisses, oral commerce, being in love. However, this relationship is between two adults of different species:

Ms Cayenne Pepper continues to colonize all my cells - a sure case of what the biologist Lynn Margulis calls symbiogenesis. I bet if you checked our DNA, you'd find some potent transfections between us. Her saliva must have the viral vectors. Surely, her darter-tongue kisses have been irresistible. ... We have had forbidden conversation; we have had oral intercourse; we are bound in telling story upon story with nothing but the facts. We are training each other in acts of communication we barely understand. We are, constitutively, companion species. We make each other up, in the flesh. Significantly other to each other; in specific difference, we signify in the flesh a nasty developmental infection called love. This love is an historical aberration and a naturalcultural legacy. (The Companion Species Manifesto 3)

In addition to referring to symbiogenesis, that is, the ways in which Cayenne and Haraway are corporeally and constitutively companion species, Haraway describes this narrative later as "soft porn," and professes to being "in love" with "the real critters, like Cayenne" (Gane and Haraway 144). It becomes clear that loving a dog in this way - becoming companion species in this very specific way - is what is indistinguishable from curiosity about what this particular dog thinks and wants (see also Despret), not a wish that the animal companion should exist just to fulfill the human's needs. There is no unconditional love to be received from a nonhuman companion. Companion species relationships are fraught with power relations, mistakes, and communication failures; they are also a product of colonial and racialized relations (Haraway, The Companion Species Manifesto 2, see also Zelinger "Unnatural Pet-Keeping"). Within this broader context, the practical attempt to build a relationship emerges. Under these conditions, the ideal for acting as a companion species is to regard another as a significant other, "to have regard for, to see differently, to esteem, to look back, to hold in regard, to hold in seeing, to be touched by another's regard, to heed, to take care of" (Haraway, When Species Meet 164). Crucially, such regard also enables humans to see nonhuman animals as more than a product of their genes, which is an important aspect of how Haraway's thinking links to queer theory.

In When Species Meet, Haraway describes an instance of Cayenne enjoying herself with Willem, an intact twenty-month old Great Pyrenees:

Humanimalia: a journal of human/animal interface studies

Volume 12, Number 1 (Fall 2020) 
Willem lies down with a bright look in his eye. Cayenne looks positively crazed as she straddles her genital area on the top of his head, her nose pointed towards his tail end, and presses down and wags her backside vigorously. (When Species Meet 193)

This occurs while Willem:

...is trying for all he's worth to get his tongue on her genitals, which inevitably dislodges her from the top of his head. Looks a bit like the rodeo, with her riding a bronco and staying on as long as possible.

Haraway adds that they repeat this again and again, and that "( $\mathrm{t})$ hey have slightly different goals in this game, but both are committed to the activity." What is interesting in this play for my argument is the following:

...(n)one of their sexual play has anything to do with remotely functional heterosexual mating behavior-no efforts of Willem to mount, no presenting of an attractive female backside, not much genital sniffing, no whining and pacing, none of all that 'reproductive' stuff. No, here we have pure polymorphous perversity that is so dear to the hearts of all of us who came of age in the 1960s reading Norman O. Brown.

I suggest that Haraway's stories about dog love can be read and developed as an intervention into queer feminist animal studies in at least three ways. First, Haraway's work includes an important critical edge, where nonhuman animals are not merely seen as a product of their genetic inheritance and their behavior is not viewed as a function of promoting a reproductive future. Haraway's work also aligns with the feminist scholarship that has long questioned gendered and heterosexualized ways of doing science (e.g., Keller and Longino). In terms of nonhuman animals, this includes questioning the ways in which scientists' heteronormative perceptions have prevented them from reporting variations in the sexual behavior of nonhuman animals. Heteronormativity has entailed explaining away all same-sex activities that seem to question the "heterosexuality" of nonhumans and in denying both the creative variety of nonhuman behavior and the sexual nature of practices such as mounting that do not contribute to reproductive purposes (Alaimo 54; Despret 136). The significance of this critique lies in the potential to acknowledge nonhuman animals as "cultural beings" and actors "enmeshed in social organizations," as in the following claim: 
In terms of environmental ethics and politics, it is crucial to acknowledge animals as cultural beings, enmeshed in social organizations, acting, interacting, and communicating. An understanding of animal cultures critiques the ideology of nature as resource, blank slate for cultural inscription, or brute, mechanistic force. (Alaimo 60)

In other words, from this queer theoretical perspective, nonhuman animals need to be seen as agents that are creative and whose behavior is not automatically determined by their genes. Instead, nonhuman animals should be seen as capable of joy, play, and enjoyment of nonreproductive sexuality - or "polymorphous perversity," as Haraway calls it in the quotation cited above.

Second, in relation to race, Haraway notes her whiteness and the conceptualization of Cayenne as "pure-bred" (The Companion Species Manifesto 2). Their love is not innocent; instead, they are both "offspring of conquest, products of white settler-colonies": "we play a team sport called agility on the same expropriated Native land where Cayenne's ancestors herded merino sheep ... imported from the already colonial pastoral economy of Australia to feed the California Gold Rush 49ers." In other words, loving nonhuman animals is not innocent. These relations are saturated with power that exceeds the immediate contact between the individuals and the power of the individual human over the nonhuman companion's living conditions, including racialized societal structures and colonial histories (see also Zelinger). I see Haraway's intervention as potentially aligned with a range of critical interventions to queer theory and to colonial understandings of sex and family that analyze sexuality and kinship as racialized (e.g., Bakshi et al.; Eng; Johnson; Rifkin; TallBear).

To explore further the idea that racialized and class-related family norms are imbued in encounters with nonhuman animals, including the context of animal advocacy, I use an illustrative example from Harlan Weaver's work. When analyzing campaigns to save pit bull terriers, Weaver notes that animal advocacy in the United States is typically shaped by race and class as well as tropes of family and citizenship, including campaigns featuring "mostly white, mostly heterosexual families living in houses with backyards" ("Pit Bull Promises" 348). Advocacy for pit bulls is permeated by familyrelated terminology: "(f)amily is prominent in their stories, with mom, dad, aunt, uncle, sister, and brother as recurrent markers for the dogs' interactions" (347-348). Pit bulls are also presented as good citizens enabled by advanced training, after which they can pass tests and acquire the title of, for example, Canine Good Citizen, or may compete in sports or work as therapy dogs that listen to children as they practice reading (347).

Humanimalia: a journal of human/animal interface studies

Volume 12, Number 1 (Fall 2020) 
Weaver's work illustrates that racialized and class-related expectations of being a proper family member, a good citizen, and a productive member of society are extended to nonhuman animals. This includes expectations of nonhumans fitting into these ideals of being a family member and a well-behaving citizen, as well as images of white and middle-class families enhancing the value of these nonhuman animals. One crucial contribution of queer theory to critical feminist animal studies is that it denotes these normative constructions of family, kinship, and citizenship, and problematizes the ways in which the value of domestic nonhuman animals is tied to these understandings.

Third, I see the type of queer theoretical intervention that can be inspired by Haraway as inclusive of the critique of compulsory sexuality and the ethics of antimonogamy (see Rosa; Willey). This broadens the alternatives to heteronormative family and relationship ideals to include significant relations with nonhuman animals.

Queer love in other registers than sex and couplehood. Even though I am focusing on Haraway, it is useful to note that, in the literature, expressions about love and intimacy that could be captured by the notion of a romantic-type relationship rather than any other mainstream conceptualization of love for nonhuman animals (e.g., friendship, parental love) also occur in the works of others. These accounts highly value dog companions in particular. For example, in the book, Loving Animals. Toward a New Animal Advocacy, Kathy Rudy conceptualizes relationship preferences in the following way: "It's not so much that I am no longer a lesbian, then, it's that the binary of gay and straight no longer has anything to do with me. My preference today is canine" (41). In her article, "I married my dog," Alice Kuzniar discusses early and mid-twentieth century literature about dog love. For Kuzniar, dog love points towards the possibility of a queer rethinking of love and family constellations, offering a "radically open alternative to common social partnerings" (209). What is queer in human-dog relationships is that the passion for dogs "opens up the subject in unique ways that, precisely because independent of gender and sexuality, are liberating" (208). I contest the idea that such relationships are totally independent of gender, but I agree that there is also a point to querying - and queering - relationships in terms other than sex or sexuality. Haraway's conceptualization of her relationship with Cayenne and the other excerpts I have cited have inspiring affinities with queer theory precisely because they conceptualize love and even romantic or erotic love in registers other than sexuality. ${ }^{11}$ Here, my reading has a slightly different focus than Margret Grebowicz and Helen Merrick, who are rare in their serious engagement with a queer theoretical reading of Haraway's work on nonhuman animals. ${ }^{12}$

Kuura Irni -- Queering Multispecies Bonding: Reading Donna Haraway's Dog Stories as Queer Feminism 
Grebowicz and Merrick argue that, in terms of queer theory, Haraway is not only showing that nonhuman animals have unreproductive sex; the point is to complicate the human-animal distinction from the perspective of the agency of nonhuman animals. Reading Haraway in relation to Judith Butler's political philosophy and Jacques Derrida's work on animals, Grebowicz and Merrick argue that, in both Haraway and Derrida, "animal understood as a sexual agent becomes the figure of radical possibility and openness" and "animality explodes the universalizing category of nature as homogeneous and predictable" (Beyond the Cyborg 39). I agree with Grebowicz and Merrick; a crucial move in Haraway's thinking is to question the understanding of nonhuman animals as a part of nature that is assumed to be "stable, predictable, and controllable" (38). However, Grebowicz and Merrick concentrate on the sexual agency of dogs, and in doing so, they bind the analysis of queer and sex conceptually together.

Discussing Haraway's thinking in relation to Judith Butler's, Grebowicz and Merrick note the importance in Haraway's work of nonreprocentric models of kinship, which give "sexuality a domain separate from kinship" and open "kinship to a set of community ties that are irreducible to family" (Butler, Undoing Gender 127; see also Grebowicz and Merrick 46). They cite the Introduction to The Haraway Reader, where Haraway refers to her "queer family," which includes "feminists, anti-racists, scientists, scholars, genetically engineered lab rodents, cyborgs, dog people, vampires, modest witnesses, writers, molecules, and both living and stuffed apes..." (Haraway, "Introduction" 3). Grebowicz and Merrick note that this is an example where, in Haraway, "queer kinship goes well beyond the human 'family' to include all kinds of organisms and animals" (Grebowicz and Merrick 46). ${ }^{13}$ I would like to expand upon this example of a "queer family" - Haraway's writing companions or interlocutors when doing theory.

In my reading, Haraway's work resonates with a genealogy of feminist and queer critiques of monogamy and the claiming of erotic autonomy (see Klesse), in the sense that Haraway's narratives and interviews present constellations of close human relationships that include nonmonogamy, communal living, and significant relations that go beyond couplehood (How Like a Leaf 28, 32-33, 62-63). Haraway's work also presents a sort of love story with a dog that extends the possibility of falling in love beyond relationships with other people. Finally, Haraway's work includes an account of erotic pleasure between her dog companion Cayenne and the dog Willem that exceed reproductive sex. Importantly, Klesse's article makes clear that, in the feminist genealogy, erotic autonomy has not been a question of mere choice related to liberal

Humanimalia: a journal of human/animal interface studies

Volume 12, Number 1 (Fall 2020) 
individualism. Unlike the discourses about nonmonogamy or polyamory found in contemporary popular publications that bypass questions about social injustice, in the feminist and queer genealogy that Klesse traces from the nineteenth and early twentieth century onwards critiques of monogamy and heterosexual marriage have been linked to community building and struggles against systemic oppression. For example, these have included criticizing racialized imaginaries related to sexuality and the mobilization of compulsory monogamy for imperialism (Klesse 221; see also e.g. McClintock; Willey). In Haraway's recent texts, stories are told in order to explore flourishing and "response-able" relations with nonhuman animals, assessing a range of injustices and complexities in this process (e.g., Staying with the Trouble 114-116).

However, Klesse's genealogy of feminist critiques of monogamy significantly focuses on erotics and on sex, sexual autonomy, and sexual partners. What I read as important in Haraway's stories, regarding maybe an erotic (the kisses!) but not in any conventional sense a sexual relationship with a dog, is an affinity with sex-neutral ${ }^{14}$ queer theory that is inclusive of asexuality, nonsexual significant relationships, and the critique of compulsory sexuality. Inspired by Becky Rosa's article "Anti-monogamy: A Radical Challenge to Compulsory Sexuality," Angela Willey (Undoing Monogamy 96) has aptly noted that it is not self-evident to "associate 'falling in love' with sex," and "to make sex a central organizing principle of our relationships" (for analyses of asexuality see Cerankowski and Milks). I discuss Willey's work at some length because it enables me to connect Haraway to one important feminist and queer genealogy: finding alternatives to the ideal and norm that link sex, couplehood, and monogamy to significant relationships.

In addition to black and queer genealogies in feminist thought, Willey is inspired by Alison Bechdel's Dykes to Watch Out For, a comic strip that ran from 1983 to 2008, compiled into thirteen collections, and the positive response it has received as a welcome alternative to the recently developed homonormative views of lesbian cultures, which are based on assimilating queer culture to the nuclear family and the couple normative way of life (97). Inspired by the world of Dykes to Watch Out For and Becky Rosa's distinction between nonmonogamy and antimonogamy, Willey develops what she calls the dyke ethics of antimonogamy (96-97; Rosa, "Anti-Monogamy"). Even as I appreciate the roots of this term in Willey's thinking with dyke cultures and her posing of dyke as a politicized category (98-99), for me the reference to "dyke" still restricts the potential of the "ethics of antimonogamy" for subcultures that strive also to be inclusive of trans masculine and nonbinary genders. Therefore, I drop the word "dyke" from being a defining feature of the ethics of antimonogamy as I use this term. I 
also want to stress that the ethics of antimonogamy does not refer to the opposition to or critique of monogamous relationships, per se; rather, it refers to the critique of the thought patterns and practices that connect sex, romance, couplehood, and the nuclear family as the ideal and normative relationship pattern and way of life.

As presented by Willey, the ethics of antimonogamy somewhat resembles the notion of "relationship anarchy" (Nordgren), a term for relationship constellations in which a romantic and/or sexual couple relationship is not necessarily preferred hierarchically over other relationships, but where intimate relations can consist of both sexual and/or romantic and other close relationships. However, the way in which Nordgren pictures relationship anarchy can be construed as being individualistic and ableist. Even though Nordgren mentions commitments, such as child care, as possibilities for relationship anarchists, the text assumes everyone to be "autonomous individuals" (first paragraph) who do not need to compromise in relation to other people's (or nonhuman animals') needs or wishes. Thus, the challenges associated with Nordgren's conceptualization of relationship anarchy are similar to those of other popular criticisms of monogamy pointed out by Christian Klesse, such as individualism and the lack of engaging with social injustices, which create dependencies and provide better possibilities for some people to act as autonomous individuals in comparison to others (Klesse 221). Despite this critique, relationship anarchy is worth mentioning in this context; because it does not restrict significant relationships or loved partners to sexual or romantic relationships it resists normative constructions about which relationships count as significant and what kinds of commitments one is supposed to make.

Nordgren's text is also anthropocentric; it does not discuss the possibility of significant relations with nonhuman animals. In contrast, Willey includes a few mentions of nonhuman animals, who are part of the relationship constellations in the world of Bechdel's comics. For example, in writing about, Mo, one of Bechdel's protagonists, Willey notes that "her single life is not a lonely one marked by lack," because "(b)esides her long-term relationship with two cats, Vanessa and Veronica, Mo has an extended family of friends and exes" (109-110). Of Ginger, another protagonist, Willey also notes that "(h)er primary affective ties are without doubt with her dog of many years, Digger, whose death is a major event in the comic, the community, and Ginger's life" (112).

Willey does not, however, speculate about what accounting for significant nonhumans might do for understanding the ethics of antimonogamy. I share with Willey the appreciation of the ethics of antimonogamy, which is grounded "in notions of friendship, community, and social justice" and which "decenters the sexual dyad"

Humanimalia: a journal of human/animal interface studies

Volume 12, Number 1 (Fall 2020) 
(Willey 97). I see these thoughts as compatible with Haraway's understanding of kinship. I suggest that the strength in Haraway's story about Cayenne is that it allows for including nonhuman animals in a broader spectrum of possibilities to think about significant others and intimate relationships. When Haraway is read through the feminist and queer theoretical work I discussed above, her thinking can be seen to develop the strand in feminist theory and practice where the norms that set monogamy and the couple as the core intimate and sexual relationship, and to which everything else becomes secondary, are questioned. Haraway's work can be read as inspiration for developing queer feminist work where relationships with friends and communities, asexual or nonsexual relationships, and relationships with nonhuman animals can be considered no less valuable than romantic and sexual partnerships with other people.

Concluding remarks: Queering multispecies bonding. In this paper, I have explored what a queer feminist animal studies approach might indicate when it is understood as a critique of norms related to family and intimacy. I suggest that developing sustainable possibilities for multispecies bonding benefits from a dialogue with queer theoretical work. One way to support the development of multispecies bonding is to combine it with questioning the normativity of monogamy, the coupling of sexuality with romance, and other anthropocentric, racialized, and class-related ideals of families and relationships. This requires attending to the existing critique of white, colonial histories and practices of kinship; as for example, Kim TallBear writes in a contribution to the Special Issue Queer Inhumanisms: "indigenous peoples have never forgotten that nonhumans are agential beings engaged in social relations that profoundly shape human lives" (234). A queer theoretical perspective can contribute to feminist animal and multispecies studies and the understanding of multispecies bonding by questioning the a priori, assumed Western hierarchy between romantic and sexual relationships versus friendships or other nonsexual or asexual relationships, including relationships with nonhuman animals. I suggest that reading both Angela Willey's ethics of antimonogamy and Haraway's story about Cayenne as such critique helps one think through intimacy, significant others, and romantic relationships more broadly than merely seeing them as sexual relationships between people. In turn, this helps in conceptualizing significant and loving relations between people and their nonhuman companions, providing an alternative to conceptualizing the love for nonhuman companions via the cultural narratives of parental love or friendship. One key point in critical animal studies and the Haraway-inspired queer feminism developed here is to not only ask how queer theorization that includes nonhumans facilitates questioning people's heteronormative kinship constellations (e.g., Bibler; McKeithen), but to focus on how developing multispecies bonding also sustains the thriving of the nonhumans 
that are part of these relationship constellations. This requires the human partner to be curious about and have regard for the individual nonhuman-their needs, wishes, characteristics, and conditions for flourishing. When viewed from Haraway's perspective, understanding companion species as "a permanently undecidable category" (When Species Meet 165) requires avoiding assigning the animal companion into any predetermined category - such as a child. Instead this approach requires attending to both the specific and individual differences at work in the relationship.

As I have suggested, according to Haraway's critique, it seems that it is extremely problematic to assume a nonhuman (in her case, a dog) is one's "furry baby." Haraway poses the infantilization of dogs and the need to rethink categorization as the central problem, which I read as part of the negotiation of the particular kind of otherness of a specific nonhuman animal. First and foremost, Haraway's critique of considering a relationship with a nonhuman as being similar to that of a parent-child relationship focuses on the categorization of the adult dog (as infantile, as child). Consequently, in Haraway's work, discussion about the corresponding cultural trope available for making sense of the affection on the part of the human ("parental love") is foreclosed. However, parent-child relationships do not merely involve small children; a grown-up can still be someone's child, and any sustainable parenthood is hardly compatible with making predetermined assumptions about the characteristics of the child. Furthermore, subcultures, such as drag and ballroom scenes, proliferate with alternative kinship systems, including houses, mothers, and children, which are not based on biological ties (e.g., Butler, "Gender Is Burning" 391). These kinship systems bear little resemblance to the white middle-class conceptualizations of familial relationships criticized by Haraway. Possibly, they could inspire feminist animal and multispecies studies to think about parent-child relationships in new ways. Interestingly, Haraway's proposal to "unravel the ties of both genealogy and kin, and kin and species" (Staying with the Trouble 102) extends to the rethinking of romantic love with an adult partner as nonanthropocentric, but not to any possibility to reconsider parent-child relationships from a queer perspective.

I have argued that Haraway's storytelling about dog love is extremely relevant. When read in relation to the queer theoretical critique of norms, it provides one way of destabilizing the normative ideals of relationships, and it helps compose alternative stories of multispecies bonding. Such a queer theoretical approach contributes to the tools that help conceptualize closeness and intimacy without the need to assume that people can only have significant, close, and loving relationships with other humans. Initiating a discussion about these alternative relationship constellations in the context

Humanimalia: a journal of human/animal interface studies

Volume 12, Number 1 (Fall 2020) 
of feminist animal and multispecies studies provides the possibility for establishing solidarity between critical animal studies and queer activist and scholarly attempts to question heteronormative, anthropocentric, racialized, and class- and couple-based relationship and family norms. Queer- and trans-sensitive animal studies could be further developed that account for how gendering and racializing categorizations are involved and enhanced, and, in complex ways, regenerated in people's relationships to other animals (see also Weaver, "Feminisms" 12). Thinking about multispecies bonding in the context of queer feminism also contributes to broadening the focus on gender in feminist animal studies from "women and men" and their assumed sexual relationship towards a more multifaceted understanding of genders, (a)sexualities, and multispecies relationship constellations.

\section{Notes}

1. I am grateful for comments from and discussions with participants in the Network for Critical Animal Studies in Finland, members of the research project, Climate Sustainability in the Kitchen - Everyday Food Cultures in Transition, members of the group, Slow Academy for Anti-authoritarian Queer and Trans Thinking, friends in my queer and nonbinary communities, and anonymous reviewers. I will continue to think through the comments and discussions in my future work.

2. See Bibler, "Capote's Frozen Cats"; Despret, What Would Animals Say If We Asked the Right Questions?; Gaard, "Toward a Queer Ecofeminism"; Giffney and Hird, Queering the Non/Human; Stanescu, "Species Trouble: Judith Butler, Mourning, and the Precarious Lives of Animals"; Steinbock, Szczygielska, and Wagner, Tranimacies. Intimate Links between Animal and Trans* Studies; Weaver, "Pit Bull Promises" and "The Tracks of My Tears."

3. Haraway, The Companion Species Manifesto 11; When Species Meet 51, 52, 67; "Cyborgs, Coyotes and Dogs" 331; and Haraway in Potts and Haraway 326.

4. Haraway's "Make kin, not babies!" slogan has also elicited a critique of Haraway as "trafficking irresponsibly in racist narratives" (Lewis 12). This is because Haraway suggests that fewer humans are needed on this planet; however, according to the critics, Haraway does not sufficiently explain how the number of people might in practice be reduced in order to avoid coercive methods or even genocide (Lewis; J. Turner, "Life with Ms Cayenne Pepper"). This critique, which is extremely important, in my interpretation reads Haraway as proposing a normative way of behaving. For example, 
according to Lewis (6), Haraway is giving "antinatalist instructions." From the perspective of Lewis' reading, Haraway's recent work appears problematic and far from useful. However, in my paper, I explore reading Haraway from the perspective of a critique of norms. In other words, the inspiration I draw from Haraway's work is not about imposing childlessness on others; it is about the possibilities the dog stories offer for rethinking norms and assumptions related to family, relationships, and sex that are imposed on both people and nonhumans. This opens up possibilities for alternatives rather than closing them down.

5. See for example McKeithen, "Queer Ecologies of Home: Heteronormativity, Speciesism, and the Strange Intimacies of Crazy Cat Ladies"; TallBear, "Making Love and Relations beyond Settler Sex and Family"; Weston, Families We Choose: Lesbians, Gays, Kinship; and Willey, Undoing Monogamy: The Politics of Science and the Possibilities of Biology.

6. Haraway's studies have elicited critiques from within ecofeminism and critical animal studies for a range of reasons; for example, because Haraway has accepted the use of nonhuman animals in laboratories and food production. (For critiques of Haraway, see, e.g., Donovan, "Animal Ethics, the New Materialism, and the Question of Subjectivity”; Giraud, "Beasts of Burden:' Productive Tensions between Haraway and Radical Animal Rights Activism"; Karhu, From Violence to Resistance: Judith Butler's Critique of Norms 97-98; and Weisberg, "The Broken Promises of Monsters: Haraway, Animals and the Humanist Legacy."). However, in this paper I suggest that, despite these aspects of Haraway's work, the thinking about significant multispecies relationships - which, in particular, in Haraway's work, concerns people and dogsand specifically the affinity I see in Haraway's work with queer theoretical critique of norms, can also be useful for critical animal studies.

7. See also Despret; Grebowicz and Merrick 113; Hemmings, Why Stories Matter. The Political Grammar of Feminist Theory; Swanson et al. "Introduction. Bodies Tumbled into Bodies" 8-10; and Tsing, "Unruly Edges: Mushrooms as Companion Species.”

8. In particular, Grebowicz and Merrick read Haraway in relation to Judith Butler's thinking (Beyond the Cyborg 43-44).

9. For an overview of the critique, see Cudworth, Social Lives 149-154.

Humanimalia: a journal of human/animal interface studies

Volume 12, Number 1 (Fall 2020) 
10. In addition, for an analysis of dogs in relation to consumerism and companionanimal industries, see Haraway, When Species Meet 47-55.

11. At least one reader seems perplexed about Haraway's story about Cayenne in Companion Species Manifesto, and asks: "She is letting Ms Cayenne Pepper plant 'dartertongue kisses' in her mouth. Is this dog abuse, pack psychology, mere gambolling? Is it something so subtle and particular that we need to work to find the words?" (J. Turner, "Life with Ms Cayenne Pepper"). I agree that this is something we need to find words for, and my paper is one attempt to address this. However, I do not read Haraway or the other writers I discuss as promoting dog abuse. Due to space limitations, I narrow the focus of this paper by not discussing bestiality. For existing analyses of bestiality, see Brown and Rasmussen, "Bestiality and the Queering of the Human Animal"; Grebowicz, "When Species Meat: Confronting Bestiality Pornography"; and C. Taylor, "Sex without All the Politics?"

12. Lynn Turner has also discussed Haraway's work in her article, "When Species Kiss." Turner focuses on the interspecies kiss in texts by Donna Haraway and Hélène Cixous and the photography of Carolee Schneemann, connecting this discussion to Derrida's encounter with a cat in "The Animal That Therefore I Am (More to Follow)." In particular, Turner focuses on performativity in Derrida's work via its connections to these other scholars. Turner's central argument is that these scholars and/or artists "turn the tables and question our certainty regarding our own clarity of communication; they transform the terms of the alleged privation of the animal with regard to language" (67). Haraway's earlier writings, most notably, on cyborgs, have elicited more discussion about her connections with queer theory (see for example, Cox, “Decolonial Queer Feminism").

13. Joseph Schneider also mentions Haraway's "queer family of companion species" (58), without, however, analyzing or further developing the notion of queer.

14. Megan Milks promotes the notion of "sex-neutrality" in place of "sex-positivity" in order to be more inclusive of asexuality: "'sex-neutrality' invokes the same respect for diversity originally implied by sex-positivity without assuming sexual desire or suggesting sex is inherently positive" (114). 


\section{Works Cited}

Alaimo, Stacy. "Eluding capture: The Science, Culture, and Pleasure of 'Queer' Animals." Queer Ecologies. Sex, Nature, Politics, Desire. Catriona Mortimer-Sandilands and Bruce Erickson, eds. Indiana UP, 2010. 51-72.

Bakshi, Sandeep, Suhraya Jivraj and Silvia Prosocco, eds. Decolonizing Sexualities. Transnational Perspectives, Critical Interventions. Counterpress, 2016.

Bibler, Michael P. “Capote’s Frozen Cats.” Angelaki 23.1 (2018): 116-130.

Birke, Lynda. "Naming Names-or, What's in It for the Animals?" Humanimalia 1.1 (2009). 1-9. Online.

Brown, Michael, and Claire Rasmussen. "Bestiality and the Queering of the Human Animal." Environment and Planning D: Society and Space 28.1 (2010): 158-77.

Butler, Judith. Undoing Gender. Routledge, 2004.

. "Gender Is Burning. Questions of Appropriation and Subversion." Dangerous Liaisons: Gender, Nation, and Postcolonial Perspectives. Anne McClintock, Aamir Mufti and Ella Shohat eds. U of Minnesota P, 1997. 381-95.

Cerankowski, Karli June, and Megan Milks, eds. Asexualities. Feminist and Queer Perspectives. Routledge, 2014.

Cudworth, Erika. Social Lives with Other Animals. Tales of Sex, Death, and Love. Palgrave Macmillan, 2011.

Derrida, Jacques. "The Animal That Therefore I Am (More to Follow)." Trans. David Mills. Critical Inquiry 28.2 (2002). 369-418.

Despret, Vinciane. What Would Animals Say If We Asked the Right Questions? Trans. Brett Buchanan. U Minnesota P, 2016.

Donovan, Josephine. "Animal Ethics, the New Materialism, and the Question of Subjectivity." Critical Animal Studies. Towards Trans-Species Social Justice. Atsuko Matsuoka and John Sorenson, eds. Rowman \& Littlefield International, 2018.

Humanimalia: a journal of human/animal interface studies

Volume 12, Number 1 (Fall 2020) 
- "Interspecies Dialogue and Animal Ethics: The Feminist Care Perspective." The Oxford Handbook of Animal Studies. Linda Kalof, ed. Oxford UP, 2014. 1-20.

Edelman, Lee. No Future: Queer Theory and the Death Drive. Duke UP, 2004.

Eng, David L. The Feeling of Kinship. Queer Liberalism and the Racialization of Intimacy. Duke UP, 2010.

Fox Keller, Evelyn, and Helen Longino, eds. Feminism \& Science. Oxford Readings in Feminism. Oxford UP, 1996.

Francione, Gary L. Introduction to Animal Rights: Your Child or the Dog? Temple UP, 2000.

Fudge, Erica. Pets. Acumen, 2008.

Gaard, Greta. "Toward a Queer Ecofeminism." Hypatia: A Journal of Feminist Philosophy, 21.1 (1997): 114-37.

Gane, Nicholas, and Donna Haraway. "When We Have Never Been Human, What is to Be Done? Interview with Donna Haraway." Theory, Culture \& Society 23.7-8 (2006): 13558.

Giffney, Noreen. "Denormatizing Queer Theory. More than (Simply) Lesbian and Gay Studies." Feminist Theory 5.1 (2004): 73-78.

Giffney, Noreen, and Myra J. Hird, eds. Queering the Non/Human. Ashgate, 2008.

Giraud, Eva. "'Beasts of Burden:' Productive Tensions between Haraway and Radical Animal Rights Activism." Culture, Theory and Critique 54.1 (2013): 102-20.

Grebowicz, Margret. "When Species Meat: Confronting Bestiality Pornography." Humanimalia 1.2 (2010): 1-17.

Grebowicz, Margret, and Helen Merrick. Beyond the Cyborg; Adventures with Donna Haraway. Columbia UP, 2013. 
Haraway, Donna J. The Companion Species Manifesto. Dogs, People, and Significant Otherness. Prickly Paradigm Press, 2003.

. "Cyborgs, Coyotes, and Dogs: A Kinship of Feminist Figurations." The Haraway Reader. Routledge, 2004. 321-32.

_ How Like a Leaf. An Interview with Thyrza Nichols Goodeve. New York: Routledge, 2000.

. "Introduction: A Kinship of Feminist Figurations." The Haraway Reader. Routledge, 2004.3-6.

. "The Promises of Monsters: A Regenerative Politics for Inappropriate/d Others." The Haraway Reader. Routledge, 2004. 63-124.

. Staying with the Trouble. Making Kin in the Chthulucene. Duke UP, 2016.

.When Species Meet. U Minnesota P, 2008.

Hemmings, Clare. Why Stories Matter. The Political Grammar of Feminist Theory. Duke UP, 2011.

Hird, Myra. "Animal Trans." Queering the Non/Human. Noreen Giffney and Myra Hird, eds. Ashgate, 2008. 227-47.

Karhu, Sanna. From Violence to Resistance: Judith Butler's Critique of Norms. Academic PhD dissertation. Faculty of Arts, University of Helsinki, 2017.

Johnson, E. Patrick, ed. No Tea, No Shade: New Writings in Black Queer Studies. Duke UP, 2016.

Klesse, Christian. "Toward a Genealogy of a Discourse on Women's Erotic Autonomy: Feminist and Queer-Feminist Critiques of Monogamy." Signs: Journal of Women in Culture and Society 44.1 (2018): 205-31.

Kuzniar, Alice A. "'I Married My Dog:' On Queer Canine Literature." Queering the Non/Human. Noreen Giffney and Myra Hird, eds. Ashgate, 2008. 205-26.

Humanimalia: a journal of human/animal interface studies

Volume 12, Number 1 (Fall 2020) 
Lewis, Sophie. "Cthulhu Plays no Role for Me." Viewpoint Magazine 8 May 2017. Accessed 18 June 2020. Online.

McClintock, Anne. Imperial Leather: Race, Gender, and Sexuality in the Colonial Contest. Routledge, 1995.

McKeithen, Will. "Queer Ecologies of Home: Heteronormativity, Speciesism, and the Strange Intimacies of Crazy Cat Ladies." Gender, Place and Culture 24.1 (2017). 122-134.

Milks, Megan. "Stunted Growth: Asexual Politics and the Rhetoric of Sexual Liberation." Asexualities: Feminist and Queer Perspectives. Karli June Cerankowski and Megan Milks, eds. Routledge, 2013. 100-118.

Nimmo, Richie. "Animal Cultures, Subjectivity, and Knowledge: Symmetrical Reflections beyond the Great Divide." Society \& Animals 20.2 (2012): 173-92.

Nordgren, Andie. The Short Instructional Manifesto for Relationship Anarchy, 2012. Online.

Potts, Annie, and Donna Haraway. "Kiwi Chicken Advocate Talks with Californian Dog Companion." Feminism \& Psychology. 20.3 (2010): 318-36.

Rifkin, Mark. When Did Indians Become Straight? Kinship, the History of Sexuality, and Native Sovereignty. Oxford UP, 2011.

Rosa, Becky. "Anti-Monogamy: A Radical Challenge to Compulsory Heterosexuality?" Stirring It: Challenges for Feminism. Gabriele Griffin, ed. Taylor and Francis, 1994. 107-20.

Rudy, Kathy. Loving Animals. Toward a New Animal Advocacy. U Minnesota P, 2011.

Schneider, Joseph. Donna Haraway: Live Theory. Continuum, 2005.

Stanescu, James. "Species Trouble: Judith Butler, Mourning, and the Precarious Lives of Animals." Hypatia: A Journal of Feminist Philosophy. 27.3 (2012): 567-82.

Steinbock, Eliza, Szczygielska, Marianne, and Anthony Wagner, eds. "Special Issue: Tranimacies. Intimate Links between Animal and Trans* Studies." Angelaki: Journal of the Theoretical Humanities 22. 2 (2017). 
Sullivan, Nikki. "The Somatechnics of Perception and the Matter of the Non/Human. A Critical Response to New Materialism." European Journal of Women's Studies 19.3 (2012): 299-313.

Swanson, Heather, Anna Tsing, Nils Bubandt, and Elaine Gan. "Introduction. Bodies Tumbled into Bodies." Arts of Living on a Damaged Planet. Monsters of the Anthropocene Anna Tsing, Heather Swanson, Elaine Gan and Nils Bubandt, eds. U Minnesota P, 2017. M1-M12.

TallBear, Kim. "An Indigenous Reflection on Working Beyond the Human/Not Human." José Esteban Muñoz, Jinthana Haritaworn, Myra Hird, Zakiyyah Iman Jackson, Jasbir K. Puar, Eileen Joy, Uri McMillan, Susan Stryker, Kim TallBear, Jami Weinstein, and Jack Halberstam, Theorizing Queer Inhumanisms. GLQ: A Journal of Lesbian and Gay Studies 21.2-3 (2015): 230-35.

. "Making Love and Relations beyond Settler Sex and Family." Making Kin Not Population. Adele E. Clarke and Donna Haraway, eds. Prickly Paradigm Press, 2018. $145-64$.

Taylor, Chloë. "'Sex without All the Politics?' Sexual Ethics and Human-Canine Relations." Pets and People. The Ethics of Our Relationships with Companion Animals. Christine Overall, ed. Oxford UP, 2017. 234-48.

Taylor, Sunaura. "Interdependent Animals: A Feminist Disability Ethic-of-Care." Ecofeminism. Feminist Intersections with Other Animals and the Earth. Carol Adams and Lori Gruen, eds. Bloomsbury, 2014. 109-26.

Torres, Bob. Making a Killing: The Political Economy of Animal Rights. AK Press, 2007.

Townley, Cynthia. "Friendship with Companion Animals." Pets and People. The Ethics of Our Relationships with Companion Animals. Christine Overall, ed. Oxford UP, 2017. 21-34.

Tsing, Anna. “Unruly Edges: Mushrooms as Companion Species." Environmental Humanities 1 (2012): 141-54.

Tuan, Yi-Fu. Dominance and Affection: The Making of Pets. Yale UP, 1984.

Humanimalia: a journal of human/animal interface studies

Volume 12, Number 1 (Fall 2020) 
Turner, Jenny. "Life with Ms Cayenne Pepper." London Review of Books 39.11 (1 June 2017.) Accessed 22 June 2020. Online.

Turner, Lynn. "When Species Kiss. Some Recent Correspondence among Animots." Humanimalia 2.1 (2010). 60-86. Accessed 24 June 2020. Online.

Weaver, Harlan. "Pit Bull Promises. Inhuman Intimacies and Queer Kinships in an Animal Shelter." GLQ: A Journal of Lesbian and Gay Studies 21.2-3 (2015): 343-63.

. "The Tracks of My Tears. Trans* Affects, Resonance, and Pit Bulls and Parolees." TSQ: Transgender Studies Quarterly 2.2 (2015): 345-52.

. "Feminisms, Fuzzy Sciences and Interspecies Intersectionalities. The Promises and Perils of Contemporary Dog Training." Catalyst. Feminism, Theory, Technoscience 3.1 (2017). 1-27.

Weisberg, Zipporah. "The Broken Promises of Monsters: Haraway, Animals and the Humanist Legacy." Journal for Critical Animal Studies 7.2 (2009): 22-62.

Weston, Kath. Families We Choose: Lesbians, Gays, Kinship. Columbia UP, 1997.

Willey, Angela. Undoing Monogamy: The Politics of Science and the Possibilities of Biology. Duke UP, 2016.

Zelinger, Amir. "Unnatural Pet-Keeping: Pet-Custody Disputes in the Aftermath of Hurricane Katrina." Humanimalia 9.2 (2018): 92-120. Accessed 24 June 2020. Online. 